\title{
More valuable than money: Outstanding friends groups hailed
}

\author{
By Jon Eldredge \\ Assistant Professor, University of New Mexico School of Medicine \\ and Chief of Collection and Information Resources Development, \\ University of New Mexico Medical Center Library
}

\section{New and old winners of the annual FOLUSA Award.}

$\mathrm{F}$ riends of Libraries U.S.A. (FOLUSA) has selected the Friends of the Lovejoy Library at Southern Illinois University at Edwardsville for the 1991 FOLUSA Award. The SIUE group received this $\$ 1,000$ award for implementing ambitious public relations and fundraising programs on the occasion of their 25th anniversary. Among the outstanding features of this entry was a unique friends program for honoring students.

The Friends of the Lovejoy Library at SIUE was the seventh academic library group to win a FOLUSA Award in the nine-year history of the competition. (Table 1 lists the group's accomplishments.) The FOLUSA Award, established in 1982, encourages friends groups to take bold initiatives and then to share knowledge gained through these endeavors so that other friends groups may benefit. Baker and Taylor Books donates funds for the awards; the FOLUSA Board of Directors' Awards Committee administers the selection process. Awards may be given to statewide friends groups, or to friends groups affiliated with public, school, or academic libraries. Entrants must be members of FOLUSA to be eligible for the award.

The Friends of the Lovejoy Library at SIUE won the award for an impressive array of accomplishments in 1990. The Friends increased their ranks to more than 500 members, renovated the library's rare book room readinglounge, enlarged the library endowment to more than a quarter of a million dollars, and established a "Challenge Fund" to match donations to the library by other groups or academic departments at SIUE. The Friends also expanded the number of donors by $33 \%$; individual monetary contributions rose by nearly $89 \%$.

Three annual fundraising activities heightened wider public interest in the library: an antique show

\section{TABLE I}

The 1991 winner at a glance

Friends of the Lovejoy Library, Southern Illinois University-Edwardsville

- Enlarged membership to over 500

- Library renovations

- Growth of endowment to over $\$ 250,000$

- Challenge Fund

- Increased number and amount of donations

- Successful public relations activities

- Unique program of student awards 
attended by 2,000 people, a book fair attended by several hundred, and a Good Buy Bookshop that sold used textbooks to students throughout the school year. Monies raised were devoted to developing library collections in world literature, women's studies, Black American studies, and an assortment of other disciplines.

A unique program of student awards sponsored by the Friends also caught the attention of the FOLUSA Awards Committee. For the past 24 years the Friends have granted monetary awards to SIUE students. There are now four distinct award categories. The Library Student Development Award was presented to several students in 1990 for their "extraordinary job performance" at the library. The Library Stuldent Honors Award was donated to a sophomore library employee for having the highest grade point average. The Student Teaching in English Awardhonored the student who demonstrated potential of "becoming a successful and influential teacher." Each student recognized through these three types of awards received $\$ 100$. The fourth award of $\$ 250$ is offered to an SIUE alumnus or alumna pursuing an MLS.

The FOLUSA Award selection process for academic entries was coordinated this year by Sam Streit of Brown University. In his report to the FOLUSA Board of Directors, Streit wrote: "All of the entries had something to recommend them but SIUE was the most impressive in terms of the number and variety of activities that its Friends group has undertaken and in balancing activities that stress public relations with those that provide a tangible benefit to the library."

\section{0 winner hosts fundraiser that nets $\$ 136,000$}

The Gustavus Library Associates of Gustavus Adolphus College, St. Peter, Minnesota, won the 1990 FOLUSA Award for their extraordinary achievements in fundraising and for eliciting wide member participation. The crisis of rising journal prices prompted the Associates to establish a $\$ 100.000$ endowment from which the interest earned would support needed subscriptions. Funds were raised with a single social event called "A Royal Affair-Holiday Magic" which consisted of a silent auction, dinner, and entertainment. Preliminary expenses were offset by 650 donated items for the auction, plus corporate in-kind or financial support.

Five hundred friends were involved in a highly-organized effort to plan and execute the event. More than 1,000 guests attended with a net gain of $\$ 136,000$ realized by the Associates.

The Associates' application for the FOLUSA Award reads like a PR management and fundraising textbook. The application consists of atwo-page overview, essential documentation, sample materials, abudget, and results from a thorough evaluation. The Associates' application even demonstrates how their management of this event laid the foundation for future activities. This November the Associates hope to raise at least $\$ 130,000$ to build collections representing the traditions of different peoples.

The Associates can claim a remarkable series of past accomplishments since their formation in 1977. To date they have built a $\$ 1.25$ million library endowment fund, offered continuing education programs, sponsored cultural opportumities, and provided social benefits to their members. Library director Michael Haeuser observes that the biggest benefits to the members comes from a "sense of belonging to a cherished community" and "being part of an active, dynamic group that really does something worthwhile." The Associates have benefited the library by highlighting its importance as an institution in campus life. Haeuser compares the importance attached by college alumni to this library to the loyalty alumni might feel toward athletic teams at other colleges or universities. The Associates have played an essential role in strengthening that loyalty. The Associates won John Cotton Dana Library Public Relations Awards in both 1980 and 1984; in 1987 they received the Gale Research Financial Development Award.

\section{Lectures, programs, and books fairs among exemplary programs honored by FOLUSA}

Descriptions of past FOLUSA Award winners programs reflect the diversity of activities that extend beyond the often perceived function ascribed to friends as convenient vehicles for fundraising. 
(Table 2 shows the last seven award recipients.) In 1984, for example, the Friends of the Libraries at SUNY Albany won a FOLUSA Award for a lecture series. The "Wednesday Wanderings" noontime lectures program featured faculty discussing their research projects or local speakers addressing relevant social issues.

The "Wednesday Wanderings" series has consistently attracted enthusiastic participants from the university and the community since its creation in 1981. Dorothy Christiansen, associate director for library development at SUNY Albany reports that the program, renamed "Community Conversations" in 1990, has continued to place a dual emphasis upon faculty research and public affairs. A recent talk focused upon "Criminal Justice and Its Impact on People of Color."

The Tennessee Tech University Library Friends group won the FOLUSA Award in 1985 for its innovative program of Professional Enhancement Grants to Librarians. A foundation with a modest endowment was enlarged through a well-attended annual champagne gala sponsored by the Friends. Membership fees and donations also added to the endowment.

The Professional Enhancement Grants are awarded to librarians in amounts ranging from $\$ 100$ to $\$ 1,000$ and supplement modest university travel funds enabling librarians to attend workshops or preconferences where they may receive specialized training. These grants may not be used to attend regular conferences, however. According to library. director Winston Walden, the grants continue to be a greatly appreciated service provided by the Friends.

The University of Illinois Library Friends in Urbana-Champaign won the 1986 FOLUSA Award for their concurrent efforts in fundraising and public relations. Having developed a highly successful

\section{TABLE 2}

FOLUSA Award Recipients

1984 State University of New York, Albany

1985 Tennessee Tech University, Cookeville

1986 University of Illinois at UrbanaChampaign

1987 Augustana College, Sioux Falls, South Dakota

1988 Louisiana State University, Baton Rouge

1990 Gustavus Adolphus College, St. Peter, Minnesota

1991 Southem Illinois University, Edwardsville local base of annual private support, the Library Friends launched a regional development campaign around the state. To strengthen their

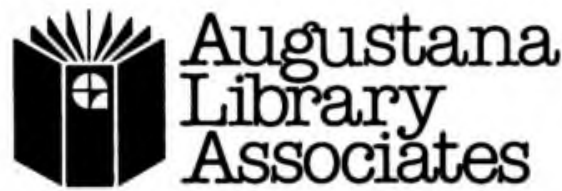

\section{This logo was used by the Augustana College Library Associates, who won the FOLUSA award in 1987.}

fundraising and public affairs position, the Library Friends developed an opinion survey to identify potential donors and to communicate more effectively with current donors. The award application described this survey as the "first of its kind to be utilized by a library friends organization, and it could be a model for friends groups nationwide." The Library Friends also conducted their first telethon to raise funds and increase membership. Other special activities during the year included a reception for new university faculty and the publication of three major exhibition catalogs.

The Augustana Library Associates, Augustana College, Sioux Falls, South Dakota, won the 1987 FOLUSA Award for their efforts to expand membership, increase donations, and sponsor special events. During the year the group built membership rolls by $83 \%$ and enlarged the treasury by $78 \%$.

The centerpiece of the Associates' extensive events schedule was a four-month celebration entitled "Shaw and Friends: An Irish Festival." This program series revolved around the donation of a 400-volume collection of works by and about George Barnard Shaw. A photography exhibit, theater performances, lectures, and evenings of traditional Irish music drew in crowds of interested people from the larger community. A grant from the Andrew W. Mellon Foundation also enabled the Associates to sponsor lectures featuring nationally known historian Arthur Schlesinger Jr. and a well- known regional author.

Library director Ronelle Thompson reports that the enjoyment and excitement generated from this activity-packed year spawned interest in new ventures. During the years since receiving the 1987 FOLUSA Award the Associates have launched "A Winter's Tale," an annual program of literature and music to celebrate the season. Thompson stresses that "A Winter's Tale" is not a fundraising activity; rather, it simply recovers costs while fulfilling broader public relations objectives of fostering goodwill toward the library. Readers may be interested in reviewing Thompson's collection of materials on 
academic library friends groups. ( $E d$. note: Friends of College Libraries, CLIP Note \#9, was published by ACRL in 1987 and is available for $\$ 17$ from ALA's Publishing Services Order Department, (800) 545-2433, press 7, or fax (312) 944-2641.)

The Friends of the Louisiana State University Library in Baton Rouge won the 1988 FOLUSA Award for exemplary group leadership, promoting strong community interest, enlarging membership rolls to 810 , and building assets of $\$ 586,000$. The leadership provided in 1974 by a retired LSU chancellor and a graduate dean emeritus revitalized this group which had been quiescent since the mid 60s. Among other achievements, the Friends helped gain legislative advocacy for construction of the third- and fourth-floor additions to the library.

Three hundred volunteers at the 12th annual Book Bazaar helped raise $\$ 38,500$. Operating expenses for this annual event were generated by the year-long Book Barn store in the library basement, which sells donated used textbooks to students. The Friends of the LSU Library have also sponsored a speakers program, rare-item auctions, special event receptions, and an annual banquet as a part of their ongoing activities. Mrs. Robert "Bill" Holtman, a major leader in the Friends, has described the

\section{FOLUSA offers ideas that work for your friends groups}

Friends of Libraries. U.S.A. (FOLUSA) is a national organization that works to develop and support local and state Friends of Library groups. There are currently over 3,000 groups with nearly 750,000 members actively working to support their libraries. FOLUSA provides its members with a network of support, ideas, and information for Friends groups. FOLUSA members have access to: Friends of Libraries U.S.A. National Notebook-a quarterly roundup of activities that work; FOLUSA Ideabank-a quarterly publication of fundraising program ideas; a legislative agenda; how-to fact sheets; a new members kit-a startup package that includes guides for drafting bylaws and samples of the above publications; the FOLUSA speakers bureau; awards; videos; and more. FOLUSA meets twice yearly in conjunction with ALA. Only FOLUSA members are eligible to apply for the FOLUSA/Baker \& Taylor Outstanding Friends of the Library Award. Application details will be published in the Spring 1992 FOLUSA National Notebook. Membership fees are $\$ 25$ for groups with less than 499 members; $\$ 35$ for groups with over 500 members. For more information or to join contact: FOLUSA, ALA, 50 E. Huron St., Chicago, IL 60611; (800) 545-2433, ext. 3222.

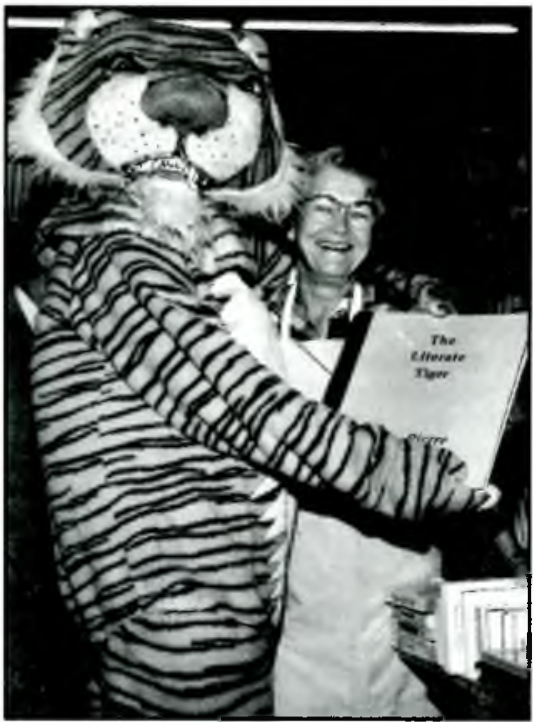

Mike the Tiger helps publicize the annual Book Bazaar held by the Friends of the LSU Library, the 1988 FOLUSA winner

Friends activities in "Portrait of a Winner: Friends of the LSU Library," in National Notebook (FOLUSA), Spring 1989.

The 1991 Friends of the LSU Library president, Mrs. Ben Hamilton, credits the members' deep commitment to "our great pride in what we' re doing for the library." She also says the Friends enjoy the "Southern style and grace" that permeates all of their special events. A major benefit for members, she says, derives from their valued interaction with the librarians and their shared love of books.

\section{Enter to win}

Applicants may be surprised by the absence of much structure found in the FOLUSA Awardapplication process. FOLUSA prescribes few strict guidelines for entrants since friends engage in a diversity of activities. Indeed, the inventory of past winners accomplishments reviewed in this article reveal that in some instances the commonly-perceived role of fundraising by friends may be altogether absent. The open-ended application form challenges entrants to clearly and concisely present their achievements in an organized manner. Competition can be stiff in any given year. That judges be able to review and understand within 20 minutes' time what the entrants have done is one wise guideline to follow.

FOLUSA Awards Committee chair Blane Dessy indicates that the judges "... look for outstanding, innovative programs that serve the library and the community." Applicants should describe theirgoals 


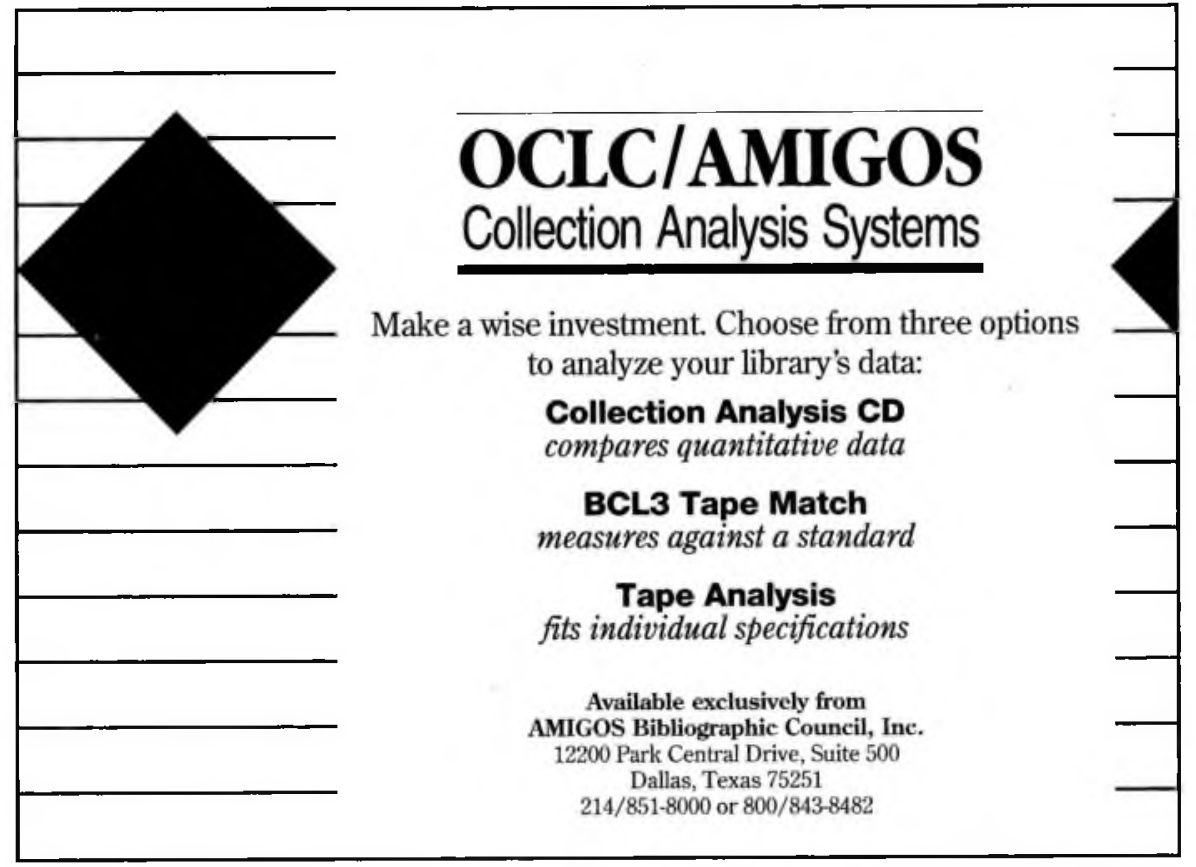

for the year and demonstrate how those goals were met. The better applications tend to place the yearlong goals in the broader context of the long-range goals set by the friends. Any novel or unique aspects of the friends' program should be emphasized.

Former FOLUSA Awards Committee chair Elaine Estes offers her shorthand criteria for winners that asks: "What effort was expended, what results were achieved? What kinds of breadth and scope did the friends' activities encompass?" To meet these criteria applicants should provide essential documentation. Winning entries typically include press releases, newspaper clippings, budgets, promotional materials, important correspondence, and any other docu-

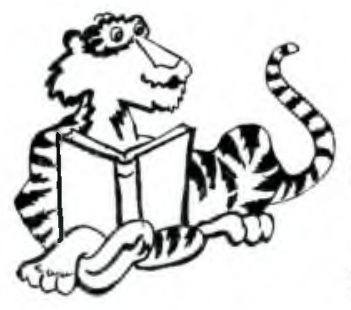

FRIENDS OF THE L.S.U. LIBRARY

The logo used by the Friends of the LSU Library, the 1988 FOLUSA winner. a group seems to be an important indication that the entrants are providing a strong link between the library and diverse groups in the community.

Dessy hesitates to recommend any winning formula. He has noticed, though, that the " ${ }^{-}$. . excellence of a program depends upon enthusiasm, good planning and careful follow-through, rather than on the size or prestige of the community or the library."

Readers interested in applying may want to review Best Ideas, 19791989 which FOLUSA distributes free to its members. This book summarizes some of the best programs sponsored by friends groups. FOLUSA membership information may be obtained from ments that will address these criteria. Growth in group membership or funds, for instance, should be presented in measurable terms.

FOLUSA executive director Sandy Dolnick has observed over the years that winning entries provide evidence of community involvement. "Programs that obviously are orchestrated by the library director do not win awards," comments Dolnick. She also notes that the variety of people involved in
ALA headquarters in Chicago. The next award entry deadline will be in early spring 1992. Winners will be honored at the FOLUSA Awards Luncheon at the 1992 AI_A Conference in San Francisco.

$E d$. note: Jon Eldredge is serving his second twoyear term on the FOLUSA Board of Directors. He's served on the FOLUSA Awards Committee and chaired the Library Administration and Managemen Association's Public Relations Section. 